Meta

Journal des traducteurs

Translators' Journal

\title{
Contextualizing Disney Comics within the Arab Culture
}

\section{Jehan Zitawi}

Volume 53, numéro 1, mars 2008

Le verbal, le visuel, le traducteur

The Verbal, the Visual, the Translator

URI : https://id.erudit.org/iderudit/017979ar

DOI : https://doi.org/10.7202/017979ar

Aller au sommaire du numéro

Éditeur(s)

Les Presses de l'Université de Montréal

ISSN

0026-0452 (imprimé)

1492-1421 (numérique)

Découvrir la revue

Citer cet article

Zitawi, J. (2008). Contextualizing Disney Comics within the Arab Culture. Meta, 53(1), 139-153. https://doi.org/10.7202/017979ar

\section{Résumé de l'article}

Cet article examine les stratégies employées par les traducteurs arabes pour contextualiser des bandes dessinées de Disney dans la culture arabe. L'accent est mis sur les traducteurs égyptiens et des pays du Golfe.

Nous essayons d'établir de quelles façons, les traducteurs arabes, fonctionnant sous la direction de trois principales maisons d'édition du monde arabe, interviennent pour adapter le texte source au contexte et à la culture cible. Nous analysons également la manière dont les caractères de Disney ont été représentés dans le texte cible, et nous examinons les nouvelles dimensions ajoutées à la performance, aux actions, au discours, etc., des caractères de Disney dans le contexte traduit. 


\title{
Contextualizing Disney Comics within the Arab Culture
}

\author{
JEHAN ZITAW I \\ Abu Dhabi University, Abu Dhabi, United Arab Emirates \\ jehan.zitawi@adu.ac.ae
}

\begin{abstract}
RÉSUMÉ
Cet article examine les stratégies employées par les traducteurs arabes pour contextualiser des bandes dessinées de Disney dans la culture arabe. L'accent est mis sur les traducteurs égyptiens et des pays du Golfe.

Nous essayons d'établir de quelles façons, les traducteurs arabes, fonctionnant sous la direction de trois principales maisons d'édition du monde arabe, interviennent pour adapter le texte source au contexte et à la culture cible. Nous analysons également la manière dont les caractères de Disney ont été représentés dans le texte cible, et nous examinons les nouvelles dimensions ajoutées à la performance, aux actions, au discours, etc., des caractères de Disney dans le contexte traduit.
\end{abstract}

\begin{abstract}
This paper examines the strategies adopted by Arab translators to contextualize Disney comics within the Arab culture, with particular reference to Egyptian and Gulf translators. The researcher attempts to establish the ways in which Arab translators, working under the supervision of three major publishing houses in the Arab world, intervene to adapt the source text to the target context and culture. The researcher also attempts to analyse the way Disney characters have been portrayed in the target text and examines the new dimensions added to Disney characters' performance, actions, speech, etc. in the translated context.
\end{abstract}

\section{MOTS-CLÉS/KEYWORDS}

Arab culture, comic translation, culture, Disney, translation strategies

\section{Introduction}

Children's comics translated from English into Arabic represent an important contribution to the literary experiences of Arab children. Notwithstanding this, translation of English comics into Arabic remains an extremely under-researched area. Doglas and Malti-Doglas (1994: 9) propose three possibilities for the adaptation of comics to the Arab cultural environment:

On one hand, we have the translation into Arabic of European adventure comics in book form, such as Tintin, Asterix le Gaulois, and Lucky Luke... On the other hand, we have completely indigenous comics, such as the Tunisian Irfan. There is yet a third possibility for Middle Eastern comics, and that is a mixture of the two: translation of foreign comics published along with indigenous forms in the same magazine.

In this, I will concentrate on the third form, "which most clearly exposes the strategies of cultural naturali[s]ation" (Doglas and Malti-Doglas 1994: 9). Disney comics, which have been translated into Arabic since the early 1960s, are an excellent example of 
the third case in which both foreign (translated) and indigenous materials are incorporated in the same publication.

\section{Aim of the Study}

My main concern in this study is to examine the strategies adopted by Arab translators to contextualize Disney comics within the Arab culture, with particular reference to Egyptian and Gulf translators. In carrying out this task, I will analyse selected translations on two main levels: textual and pictorial. Comic typography - by which I mean the appearance, type, size, font proportion and directionality of printed characters - will also be taken into consideration in my analysis. I will attempt to establish the ways in which Arab translators intervene to adapt the source text (henceforth ST) to the target context and culture. Based on my initial, tentative findings, it would seem that Arab translators use the following strategies to make the target text (henceforth TT) more acceptable and comprehensible to the target audience (Arab children in this case): reordering, addition, repetition, visual manipulation, omission, deidiomatising, and explicitation. The first five are the same strategies first presented by Delabastita $(1989,1993)$ in his analysis of film translation and the translation of puns and wordplays in the works of Shakespeare and later by Kaindl (1999) in his doctoral research on comics in translation. However, Delabastita presents a sixth strategy, namely replacement or substitution, which so far remains unattested in my research findings. The last two - deidiomatising and explicitation - represent two translation strategies that emerged during my research. Because Delabastita's translation procedures can be applied on both verbal and nonverbal levels, they have important applications in the analysis of comic translations in which pictorial and other visual elements are often as important to the act of story-telling as verbal elements. Kaindl (1999: 275) elaborates on this point by saying: "While classification schemes for translation strategies tend to focus only on verbal elements, these rhetorical concepts are also suitable for pictorial features, since semiotic studies have shown that rhetorical figures in language can all find a visual expression."

The study will also attempt to answer the following question: How has characterisation in Disney comics been influenced by the Arab translators' attempts to make the comics fit within the Arab culture? I will try to analyse the way Disney characters have been portrayed in the TT and understand the new dimensions, if any, added to Disney characters' performance, actions, speech, etc. in the translated context.

\section{Data}

The study has been conducted by looking at 108 Disney comic stories and their Arabic translations. Three major publishing houses in the Arab world, namely, Dar Al-Hilal in Egypt, Al-Futtaim Printers and Publishers in Dubai, and Al-Qabas Newspaper in Kuwait, are involved in translating Disney comics for Arab children. Dar Al-Hilal is one of Disney's oldest publishers in the Middle East, and the first to publish Disney magazines in the Arab region in 1959. Al-Futtaim Printers and Publishers, which is a joint venture between Dubai businessman Othman Al-Futtaim and a UK-based publisher, used to translate, print and publish Disney comics until March 2000 when the Kuwaiti Newspaper Al-Qabas took over six months later and is now producing 
six Disney magazines for Arab readers around the world. The 108 Arabic translations, which are currently in hand, are divided as follows: 51 Disney comic stories translated by Dar Al-Hilal (Egypt), 25 stories translated by Al-Futtaim Printers and Publishers (Dubai), and 32 stories translated by Al-Qabas (Kuwait). Most of these comics are aimed at children between the ages of 7-12 years old.

\section{Analysis and Discussion}

\section{Translation Strategies}

Starting with the microtextual level, I will present some textual, pictorial and typographic examples to illustrate the seven translation strategies used by Arab translators.

Reordering means a change in the order of the textual and graphic elements of the source text. Delabastita (1989: 199-200) refers to this strategy as transmutati: "the components of the sign are repeated in a somewhat different internal order." Since Arabic comics, unlike Western ones, are read from right to left, the panels are reversed in printing. Accordingly, the positioning of the characters is also changed. This kind of reordering can cause a range of problems, not only because it renders right-handed characters as left-handed, thus over-representing a less common feature of life, but also because it may indirectly influence the manners of Arab Muslim children who may be expected to use their right hands in most of their deeds (depending on the religious background of their families). Orthodox Islam explicitly recommends the use of the right hand and considers it more 'blessed.'

However, Dar Al-Hilal, which is a well-known publishing house in Egypt, used to follow an old technique in which the panels were reordered without affecting the positioning of the characters within the panels.

On the textual level, the position of some linguistic signs is often changed due to various reasons. For example, in Battut (No. 305, Al-Qabas, 2001), ${ }^{1}$ the position of the onomatopoeic expression 'TUNK' is changed. Donald, who is disguised as a lady writer heading to a bookshop to sign her bestseller, stumbles when his skirt catches his high-heel shoe and drops the books on the floor. In the original panel, 'TUNK' is placed near the point where the skirt had caught on to the shoe, while in the translated panel it is placed farther down where the point of collision between the floor and Donald's body is emphasized.

By changing the position of the onomatopoeic "TUNK" the emphasis is removed from the tripping point to the point where the books hit the floor. Thus, the target reader's attention is now drawn to the left side of the panel instead of the right one. Moreover, the translator has used a completely different sound to match the position of the pang. Instead of "TUNK," which represents the noise of a trip or a fall, "TAAKH!" is used to typify the sound of a big bump against the floor or the sound of a shot or punch. This kind of replacement may revolve around the dominant sounds in the different languages, since even similar transliterated consonants will have different sounds. So, while English speakers would find it easy to grasp the "TUNK!" sound, perhaps for an Arab child still developing her/his own ability in Arabic "TAAKH!" would more easily reflect the sounds that s/he is learning or has grown up with. 
Addition is referred to by Delabastita (1989: 199) as adiectio: "the sign is reproduced with a certain addition." When applied on comics, addition means adding in the translated text linguistic, pictorial and/or typographical elements which are not there in the ST. A linguistic example can be found in the story of Mickey's adventure with two famous characters of The Treasure Island and The Three Musketeers (Mickey Vol. 78 (I), Dar Al-Hilal, 1999). By providing the target reader (Arab child) with two footnotes, explaining the identity of the two main characters, the translator has succeeded in making the story more comprehensible to the target reader.

An example relating to the area of onomatopoeia is shown in two panels from Buttut (No. 306, Al-Qabas, 2001). In the original version, Donald's speed is emphasized by the curved lines and the objects that seem to be trailing behind him, while in the translated version, "Vooo!," an Arabic onomatopoeic expression, has been added twice to the target text to highlight the fast movements of Donald, who is late for work and is trying his best to get there on time.

Repetition, or repetitio (Delabastita 1989: 199), means retaining the identical form of the source textual, pictorial and typographical elements. Linguistically, this procedure represents a case of "non-translation" (Delabastita 1989: 200). According to Kaindl (1999: 275), "among the linguistic components it is most often the onomatopoeic expressions and inscriptions that are taken over in the original form." However, while examining the selected English-into-Arabic translations under study, I was able to find very few cases in which inscriptions are taken over in their identical forms and almost no cases of retaining onomatopoeia in its original form. In most cases where the original inscriptions are retained, Arab translators tend to keep the source inscriptions in the TT for various reasons which I will discuss later. In one instance, the inscription has been retained on purpose. This is in contrast to the apparent lack of attention and/or carelessness that caused an inscription to be retained in another instance, as explained below.

In Mickey (No. 293, Al-Qabas, 2000), the inscription $(2-1=1)$ on the small blackboard, on which Minnie is explaining mathematics to baby Pete with the help of Mickey, is written in English and, of course, read from left to right although the text in the speech balloons is written in Arabic and read from right to left. The translator in this example must have kept the source inscription deliberately because without his or her deliberate intervention, the inscription would have appeared in the TT as $(I=I-S)$ because of the process of reversing the order of the panels in the TT. It is difficult to explain the reasons for this deliberate retention of the inscription $(2-1=1)$ in the TT without resorting to speculation. However, whatever the real motives, the result has an interesting effect because the Western numerical system used on the blackboard inscription developed in the Arab world (although Arabs now use a different numerical system). ${ }^{2}$ This act of retention, therefore, has some significance as an indirect act of appropriation. Paradoxically, in retaining the ST inscription, the Arabic text is also effecting a re-appropriation of ST material that originated from Arabic forms in the first place. Thus, in this instance the power relations involved in the translation process are arguably subverted: it is not only the translator who is locked into the mimetic logics of translation, but in some way it is also the creators of the ST itself, since they have used a numerical system developed in Arabic many years ago. It is worth mentioning here that in this example we also find an addition on the verbal level. On the cover of one of the books, the word 
"mathematics" is added to highlight the fact that Minnie is teaching baby Pete that subject.

By contrast with the above, an inscription (30\%) is taken over in its original form in Mickey (No. 306, Al-Qabas 2001), resulting in an incoherent figure that cannot be comprehended in either language, English or Arabic ( $\circ^{\circ} \mathrm{O} \mathcal{E}$ ). This suggests that, unlike the previous example, the retention of the ST inscription is not deliberate and may be a result of lack of attention.

A pictorial addition can also be traced in the same example. In the original panel, Gyro Gearloose and his assistant - the robot Little Helper - are shopping, and something seems to have caught Gyro's eye and confused him. This leads to a question mark (?) to be put in a bubble near his head, while Little Helper has no question mark near him. In the target panel, a question mark (?) is added near Little Helper to stress the idea that the small robot with the light bulb shares the same feeling of amazement with his inventor.

Visual manipulation refers to retouching the pictorial components of the ST. Kaindl (1999: 277) defines detractio as retouching parts of the source linguistic, pictorial, and typographical elements, not only the graphic components. There could be two reasons for manipulating the image of the "pig" character, for example, in (1) Mickey (No. 304, Al-Qabas 2001) where a panel showing Goofy fighting with a security guard which is clearly illustrated to be a pig in the original panel, but once translated the black dots that emphasised the pig's nostrils were removed, and (2) Mickey Weekly Magazine (No. 265, Al-Futtaim Printers and Publishers 2000) where a pig's nose was darkened when translated to appear like one big black circle.

One strong reason may be the censorship regulations which constrain Arab translators in the Gulf area. Islam prohibits eating the flesh of pigs, which are considered filthy and unclean animals that live on offal and pigsty. This may be why the translator or the publisher opted to remove the "pig" image from the TT, leaving the target reader with the image of an unrecognisable creature. Removing the two nostrils or covering the pig's nose can also be a result of a translator or publisher exercising his or her own discretion, anticipating that people may be offended by the "pig" image. Nevertheless, the "pig" image has been left as is in the translated version of the same ST in Egypt, which is generally less conservative than Gulf countries and has a reasonable number of Christian Egyptians (see Super Mickey, Vol. 39, Dar AlHilal 1997).

Another pictorial example that highlights the highly conservative nature of the Gulf society can be found in covering parts of women's bodies in Disney comics translated in Kuwait and Dubai (see Mickey Weekly Magazine, No. 224, Al-Futtaim Printers and Publishers, 1999) where a panel shows Donald jumping into a pool and a woman in a bathing suit is cheering him on, and when translated, the woman's body was completely darkened in from neck to ankle). According to Islamic law, Muslim women should cover all parts of their bodies except their hands and faces through verses of Quran. Therefore, the appearance of female characters wearing bathing suits or dresses that reveal parts of their bodies, such as shoulders and thighs, could be offensive to the Arab reader, in general, and the Arab child, in particular, and accordingly those revealed parts have been darkened and covered.

However, this is not the case in Egyptian comics where women's bodies are kept uncovered possibly due, again, to the less conservative nature of Egyptian society. 
For instance, in Super Mickey (Vol. 41, Dar Al-Hilal 1998), one panel shows Minnie, Clarabelle and a blonde lady in a bikini strolling by at the beach. Clarabelle comments that the girl is beautiful, which does not sit too well with Minnie since a dark thunder cloud appears above her head).

In another visual example (see Super Mickey, Vol. 30, Dar Al-Hilal 1993), Uncle Scrooge's top hat was removed in line with censorship regulations and practices carried out and followed in Egypt at the time. The longstanding association of Orthodox Judaism with the wearing of top hats, and stereotypes of Jewish people being wealthy (Uncle Scrooge is a particularly well-off comic character) may have motivated the removal of Uncle Scrooge's top hat in the translated version. Fredrik Ekman, a comic expert and collector, supported this point in an e-mail sent in 2001 to Comics Database List: "Many stories are also retouched so that Uncle Scrooge's hat is removed... this is to avoid him being mistaken for a Jew." However, Shahira Khalil, the editing director of Mickey Guaib in Dar Al-Hilal, stated in a personal interview in 2001 that the reason for deleting the hat at a specific period of time was to reduce the Western image in Disney comics translated into Arabic.

Nevertheless, as shown in Mickey (Vol. 76 (II), Dar Al-Hilal 1998), Uncle Scrooge's top hat was retained in a translation produced a few years later. This may be due to recognition on the part of the translator and/or publisher that Uncle Scrooge's top hat was intended in the ST as a symbol of America rather than Judaism. Alternatively, it could be a function of changes in a broader political context, related to developing peace negotiations in the Middle East. ${ }^{3}$

Omission, or deletio (Delabastita 1993), refers to deleting parts of the source text, pictures or typographical elements. On the textual level, parts of the dialogue enclosed in speech bubbles may be completely omitted in the TT. In Walt Disney's Comics (No. 633, Gladstone, 1999), Donald and his nephews are in the woods near a spot in the Land of a Thousand Lakes. Dewey says, "The village should be just ahead," and Louie comments, "I hear angry voices," while Donald exclaims, "Look!" When translated in Super Mickey (Vol. 32, Dar Al-Hilal 1994), Dewey's sentence "The village should be just ahead!" has been omitted, as well as "angry" in "I hear angry voices," from the TT for no obvious reason. However, this could be due to the large size of the Arabic font in comparison with the English one.

A typographic omission is shown in the translation of one panel of Walt Disney's Comics (No. 630, Gladstone 1998) that shows Donald cheerfully walking side by side with his three nephews, who express their excitement about their uncle's winning. Bold is used to emphasize specific words in Dewey and Louie's statements: "You did it, Uncle Donald!" "You won fair and square!" However, the text appears in Mickey (Vol. 78 (I), Dar Al-Hilal 1999) in a normal font: "You did it, Uncle Donald!" "You deservedly won!"

Deidiomatising means simplifying the English idiom and replacing it with a less idiomatic expression. It is almost impossible to literally render an idiom from one language into another while retaining complete accuracy in the translation process. Because of the complex nature of idioms, disaggregating any idiom into its constituent words in order to examine their individual meanings will not be conducive to the accurate reconstruction of the idiom in the target text. Both languages, Arabic and English, have their share of idioms whose meanings cannot readily be determined from the meanings of the individual words. By treating the idiom "You 
won fair and square" (meaning: You won justly and according to the rules) in the afore-mentioned typographic example as a one unit of language, the translator has successfully given the embedded and indirect meaning of the idiom by rendering it as "You deservedly won."

A more metaphorical rendering can be found in Ejazah ma' Mickey (Vol. 2, Issue 12, Al-Futtaim Printers and Publishers, no year of publication) where a panel drawn in an 'old-Egyptian' style shows Mickey, Goofy, and his clone standing in a pyramid. In the original panel, an enraged voice 'utters' lightning and snakes in a balloon: "The low-born jackal who hath consumeth all the hot dogs will have to stand before me, ere I barbecue him by my own hands!" (translated as "Tell that damned person who ate my dinner that I will punish him and barbecue him alive!). Hearing the fuming statement, one Goofy turns to the other and says, "Looks like you're in for it" (translated as "That's you!"). The other Goofy replies while crossing his arms, "Leftovers don't keep!" (translated as "But he wasn't hungry!").

Although the figurative meaning of the idiom "to be in for it" has not been given in the translated speech bubble, the reader will still know that it is him - the second Goofy - who ate the dinner and, accordingly, he is in trouble. Moreover, translating "low-born jackal" as "damned person" gets across the general sense that the object of the reference is not a particularly nice person. However, the excuse given by the culpable person is not the one given in the source text. When the second Goofy explained his action by saying, "Leftovers don't keep," he was taunting the first person by saying, "Oh! I had to eat the hot dogs because the leftovers will rot if I don't." The translation of "leftovers don't keep" in the target text missed this nuance by rendering Goofy's justification for his actions as a far more simple and direct claim that his friend, the owner of the hot dogs, was not hungry.

In a different panel of the same story, two different idioms were translated in two different ways. The real Goofy and his three clones, Mickey and a scientist appear in the scientist's office. The scientist explains to Mickey and Goofy the reasons behind building a pyramid on the top of the clones' friend Zoot, whom they have known as mischievous and bad-tempered: "The high Priests considered this another good reason to build the pyramid on top of him" (translated as "Chiefs considered this as a main reason for building the pyramid on that location!"). The clones begin laughing and saying, "That Zoot is a real character!" (translated as “That's indeed Zoot!"), and "He sure can slice the baloney thick!" (translated as "He is boorish and doesn't know how to pay compliments!").

The embedded meaning of the first idiom "He is a real character" (meaning: He is an unusual person, possibly a bit mischievous) was clearly emphasized when rendered as "That's indeed Zoot!" Zoot, of course, is characterised in these terms. The second idiom presents a very interesting case of deidiomatisation. "Baloney" is a kind of corned beef or sausage usually made in Italy, but it found its way into North American slang vernacular as a reference to lies or nonsense. Thus, the comic's reference to a character being one who can 'slice the baloney thick' is roughly translatable as a claim that they lie or exaggerate a lot. This idiom is rather complex, since it combines two different idioms: "laying it on thick" (i.e., exaggerating greatly) and "talking baloney" (i.e., talking nonsense or lying). The translation, however, is an inaccurate one, since it is not possible to reduce "slicing the baloney thick" to being boorish and unable to compliment other people. In this instance, it appears that the 
translator has attempted to simplify the idiom, but has possibly been hampered by an inability to understand the original composite idiom. Since no idiom is ever literal, it appears that the translator has deidiomatised "slicing the baloney thick" to being boorish without attempting to translate the individual words of the original idiom one by one, but rather gauging the general sense of what must have been said in the source text (i.e., an uncomplimentary remark) and rendering it in the translation as an uncomplimentary remark that conveys a general sense of crudeness. The difficulty that the translators have in even correctly understanding the idioms may underline one of the reasons why they tend to simplify them, because these types of idioms are very ambiguous and often very difficult to understand and translate.

In another panel of the same story, Mickey is dragging Goofy towards a spaceship while the three clones chase after them. Mickey says, "This should prove that Goofy isn't your mate!" (translated as "This will prove that Goofy is not your mate!"). One of the clones running behind them says, "I hope this isn't a wild goose chase!" (translated as "I hope it is not just an attempt at guessing!"). Another clone asks, "What's a wild goose?" (translated as "What is guessing?").

The translator may not have fully understood the idiomatic expression "a wild goose chase," but s/he nevertheless did succeed in simplifying it by rendering it as guessing, suggesting an activity that wastes time. This translation may not adequately communicate the specific meaning of the idiom in the source text, but it still conveys the general sense that in a wild goose chase one is generally unsure of what one is doing or whether the outcome will fail.

Explicitation means expressing the target text in a more explicit way in order to aid the Arab child to fully understand the story by putting more emphasis on the words uttered by the story characters. In Mickey (No. 304, Al-Qabas 2001), we can see three examples of the translation of interjections and onomatopoeic expressions into sentences that explicate the difficult situation that has befallen Mickey and Horace and clarify their reactions to it. Horace, who is running from a giant, seeks Mickey's help: "Mickey, you've gotta help me! A giant is chasing me!" (translated as "Help me, Mickey! There is a giant chasing me!"). Mickey's expression of surprise "H-huh?!" is translated into an interjection that is usually used as an exclamation expressing surprise and disbelief - "What?," followed by an imperative in which Mickey asks his friend Horace to stop kidding - "Stop kidding!," thus making even more explicit the idea of disbelief. Furthermore, the sound effect of the giant's footsteps, represented twice by the onomatopoeic word "WHUD!" is translated in the form of two inquiries: "What is this sound?" and "What to do, Mickey?!" thus explicitate the problematic situation they find themselves in and reinforcing the visual element.

Similarly, in Mickey (No. 305, Al-Qabas 2001), Uncle Scrooge's grandsons are visiting him in jail after he lost his fortune. The shock and pain felt by them are represented by the interjection "Uh-oh!" that reflects strong apprehension and disbelief. "Uh-oh!" is more explicitly rendered in the TT as: "He looks like a vagrant." When the genitor told the boys that their uncle bit him when he brought him in, Dewey commented by saying, "Yeah? He hasn't been great to Uncle Donald lately, either!" (translated as "You should forgive him. He has lost all his fortune!"). Interestingly, the TT represents a case of producing a more cogent and efficacious justification of Uncle Scrooge's undesirable behaviour. In the ST, the only exculpation 
introduced is that the fact that Uncle Scrooge has not been nice to his own nephew, implying that he is not himself. In the TT, explicitation during the translation process produces a far stronger justification: he has lost his fortune.

\section{Characters and Characterisation}

The profile of some Disney characters has been indirectly shaped by the Arab translators' attempts to contextualize Disney comics within the Arab culture. Whether a Disney character is flat or round, static or dynamic, the way it behaves, reacts, utters the words, relates to other characters and even looks has to some degree changed because of the new Arabic context. In this part of the paper, I will present a few examples of how the characterisation of two famous Disney characters - Mickey and the Beagle Boys - is skewed as a result of the translation strategies discussed above.

\subsection{Mickey Mouse}

Mickey Mouse is the most famous character in Disney World. In fact, he is one of the most famous characters around the world. Since his first film and print appearances on 18 November 1928 and 13 January 1930 respectively, Mickey has remained a hit; he always has the good fortune to be "the right mouse at the right place at the right time" (Finch 1999: 20-21). Rich Bellancera (2000) presents Walt Disney Company's own commentary on Mickey's character and personality:

$[\mathrm{He}]$ is a clean-living, fun-loving, 'nice-guy.' He is a hard worker who puts his "all" into anything he attempts. Intelligent, quick-witted, and true optimist. Mickey is contemporary at all times. He is the kind of guy who can make things happen! He's the best! He's everyone's favorite kind of guy.

Having such a lovable character has secured Mickey a place in the hearts of millions of children around the world, including Arab children.

In the following example, among others, Mickey's character has slightly changed when presented in the Arabic context. He is no longer the bright, well-behaved character we are familiar with; he is menacing and even displays a streak of cruelty. In History Re-Petes Itself (Mickey, No. 293, Al-Qabas 2000), Mickey and Bad Pete, his mortal enemy, are going camping to celebrate Pete's birthday and his new self. While they are rowing on Wild River, their boat hits a rock and Mickey ends up hanging on to an old rotten branch, which is about to break at any minute. Thinking that Pete has become a good person, Mickey asks him to pull him up, but Pete refuses and insists on standing and waiting for Mickey to fall.

Mickey's resourcefulness and sharp mind save him from an inevitable death. He uses the Youth Ray gun and makes the branch younger and stronger, in order to catapult up on it: "I forgot to return the Youth Ray to the scientist you stole it from, Pete. Good thing I brought it along... Just in case! It made the branch younger and stronger, so I could catapult up to you on it!" However, in the TT, Mickey is portrayed as an intimidating character who threatens to use the gun on Pete to control him: "I will use this weapon on you! You will become a small child again! You will become a child, and I will become stronger than you and control you!" Thus, the TT fails to provide the target reader with a rational explanation of how Mickey saved himself and characterises Mickey as menacing rather than quick-witted and ingenious. 


\subsection{The Beagle Boys}

The Beagle Boys are a family clan of organised criminals, who are after Scrooge's fortune. They usually wear red or orange sweaters, blue trousers and caps, and black masks. They neither bear specific names nor can be distinguished from each other by any specific physical differences, other than their arrest card placards, which are a combination of $\mathbf{1 s ,} \mathbf{6 s}$, and $7 \mathrm{~s}$. The prison numbers, which always start with $\mathbf{1 7 6}$ and end with those numbers in some order, are a guide to the individual Beagles, who use them to refer to each other. The three main Beagle Boys are as follows: $\mathbf{1 7 6}$ - 167 is the clan leader and the smartest, $\mathbf{1 7 6 - 6 7 1}$ is the dumbest and tends to mess up the others' plans, and $\mathbf{1 7 6} \mathbf{- 7 6 1}$ is extremely fond of food in general and dried plums - prunes - in particular. Each six-number permutation is therefore a distinct feature of the relevant member of the gang, especially the three main Beagles.

Arab translators have followed three different methods of rendering the inscriptions, i.e., the prison numbers, on the Beagles' sweaters. In one instance, the numbers on the Beagles number plates are retained in their English form, and surprisingly the equivalent Arabic numbers are added on the top of the English ones (see Super Mickey, Vol. 40, Dar Al-Hilal 1998). Thus, the prison numbers, which usually identify the gang members, are no longer clear, and surely do not show who the leader, the dumb one, or the greedy Beagle is. The reader in this case has to completely rely on the story dialogue and action to recognise the gang members.

In the above example, the three Beagle brothers are standing in the front lawn of a house, and one of them points at an open window where a shiny statue sits on the windowsill and rhetorically asks, "I'll be dipped if that isn't an open window! Now, is it open, or is it open?" (translated as "Is this window open? Or am I imagining that it's open?"). One Beagle answers him back, "Looks open to me!" (translated as "It looks open to me!"). The third Beagle wonders, "It's open! But I see no signs of cooking!" (translated as "It's open.. But I don't smell food!"). Reading the dialogue, the reader can tell that the Beagle brother whose comment is associated with smelling food is the glutton one. The reader can also guess that the Beagle, pointing at the window, is the leader, who always comes up with ideas, and, naturally, the third member, standing in the middle, is the dumb Beagle, who is still not sure that the window is open.

In the next panel, things are clearer because of the dialogue that undoubtedly shows the trait of each Beagle. When the Beagle brothers huddle together and begin to discuss what to do next, the first with a dumb expression says, "I can't think of anything really bright to do with that open window!" The next comments, "Why, of course! It's our ticket to the kitchen!" The last with the mischievous and self-confident expression says, "Naw! Watch me!" Accordingly, the one who thinks that the open

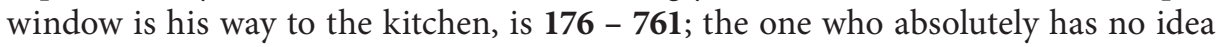
what to do with an open window and a jewelled statue resting on the edge, is 176 671; and the one who always initiates things and comes up with evil yet brilliant plans, is $\mathbf{1 7 6}$ - 167. However, the reader faces a problem of identifying two of the Beagles in the panel that follows due to the vague inscriptions on the placards. The three Beagles are running down the street, and their leader is clutching the statue he stole and saying, "Was I good, or was I good?" One of the two Beagles behind him replies, "Pretty good! wouldn't have thought of it myself!" Though the ST clearly establishes the identity of the two Beagles via the prison numbers on their sweaters, 
the TT fails to provide target readers with any clue that might help them recognize the two Beagles. When the leader asks whether he was clever, one of the Beagles asserts the leader's cleverness, saying that such an idea did not cross his mind. If this is the dumb Beagle, then a humourous effect is achieved since few ideas cross his mind, let alone this brilliant one. However, the humourous element is lost in the TT if the reader assumes that this Beagle is the gluttonous one.

The second strategy Arab translators have used to render the same inscriptions is deletion. There are two different kinds of deletion: (1) deleting the entire set of numbers and keeping the Beagles' number plates blank (see, for example, Mickey Vol. 78 (I), Dar Al-Hilal 1999) and (2) deleting the first three recurring numbers, i.e., 176, and keeping the other three numbers which distinguish each Beagle from his mate or brother (see, for instance, Super Mickey, Vol. 40, Dar Al-Hilal 1998). The latter procedure is followed in many translated Disney comics for various reasons, such as the small size of the plates, making it difficult to hold six hyphenated numbers written in Arabic, the translators' awareness that such a long number may confuse the Arab child, and the redundancy of having the first three figures in contrast to the importance of the last three numbers.

As for the third way of rendering the inscriptions, Kuwaiti translators have retained the six permutations but with a completely different order of the three main figures $-\mathbf{1}, \mathbf{6}$, and 7 . Consequently, they have deprived the reader of recognising the Beagles' identity via their prison numbers. In Mickey (No. 304, Al-Qabas 2001), the leader is rebuking the other two Beagles and telling them they should all do running exercises to keep fit. In one panel, the leader carries the number: 716 - 761, whereas his prison number in another panel is $617-\mathbf{1 6 7}$. Moreover, the dumber Beagle has been given a new number, that is 771, in the TT. Apparently, there is no consistency in rendering the Beagles' prison numbers, thus, reflecting the translators' lack of attention to or indifferent attitude towards the significance of these figures in identifying the Beagles. On the other hand, this raises the question of why the Kuwaiti translators did not see the numbers as being important to the characterisation of each Beagle. Possibly one reason for this lack of consistency in Kuwaiti translations is the difference between Western and Kuwaiti story-telling tropes. In the West, prisoners have long been subjects of cultural representation, and increasingly so in modern times. Prisoners are featured in silent movies and more modern films ("Cool hand Luke"; "The Birdman of Alcatraz") and also in their own prison comedies ("Porridge"), sitcoms centring on families separated by imprisonment ("Birds of a feather'), and dramas ("Prisoner Cell Block H"; "Bad Girls"). A common trope that emerges from many of these is the idea that the issuing of numbers to prisoners is not only a means of dehumanising them but also of determining their characterisation. This idea is, of course, explored in reverse in the 1960s cult TV programme "The Prisoner," which includes the well-known phrase "I am not a number... I am a free man!" Within the Arab world in general, and the Gulf states, such as Kuwait in particular, the same story-telling tropes and devices do not appear as relevant because they are not invested with the same significance in these areas and have not emerged from the same history of prison melodrama that occurred in the West. To a Kuwaiti reader or translator exposed to entirely different tropes of story-telling, prison numbers are incidental to the telling of a story rather than implicitly tied in with the telling of that story and the development of characterisation. 
To sum up, there are certain tropes that perform particular functions in storytelling. Some of these appear fairly commonly across many different cultures (e.g., Robin Hood stories and tales of people who take from the rich and give to the poor). But some of these tropes are more culture-specific. For example, in the colonial era a very common trope was the idea of white women being taken as hostages by nonwhite men (e.g. native American Indians, Africans, Arabs, Indians, etc.). This trope performed particular functions within a broader colonial scheme of story-telling and the construction of white Western identities. Another common trope that is peculiar to America in recent times is the idea of American soldiers being held hostage by the Viet Cong long after the Vietnam War ended (e.g., films of Chuck Norris and Sylvester Stallone and countless other American movies).

In the case of prison numbers, this is a story-telling device that emerges in Western societies from the time of the old silent movies onwards, and even though other societies have prisoners and prison numbers, they do not necessarily adopt this trope of story-telling as widely as Western societies do. Within the various genres of prison movies and TV programmes in much of the West, prisoner numbers emerge as a story-telling device that performs certain functions in telling us about life for the prisoners, and in particular in telling us implicitly about discipline, for not only does prison discipline the prisoners in a range of ways, but it also affects one's very identity. Prison numbers then act as a metaphor for these broader disciplinary processes because they conveniently and easily suggest that one's identity and personhood is reducible to a prison number. So the prison number becomes directly related to how one is characterised.

In the same way, other societies will have different story-telling tropes and devices that are not found in the West, but they are not necessarily introduced in the translated versions. In this respect, the Disney comic on the Beagle boys uses a storytelling device that is largely Western in its origins and directly informed by Western narrative traditions. This underlines the idea that Disney is not, in fact, universal, but is culture specific. You do not have Disney comics without this broader history of Western story-telling from which Disney emerges. This point can thus also be related to other ideas about Disney as being Eurocentric.

\section{Conclusion}

In one sense, the translation of Beagle Boys comics by Kuwaiti translators is a metaphor for the broader processes at work in translating comics from English into Arabic generally. The important cultural difference between Western and Gulf-Arab story-telling tropes that is reflected in the differing levels of importance invested in the Beagles' prison numbers illustrates the ways in which the translation of comics from English into Arabic is not merely a question of "finding the right words" to tell a story, but rather of attempting to make the story-telling forms of one culture accessible to members of other cultures. In this way, different strategies employed by translators of Disney comics into Arabic do not come solely to rest on simple lexical translation questions, but are rather deeply influenced by broader notions of story-telling and cultural situatedness. For these translations to work, and for Disney's comics to be successful in telling their stories in Arabic, translators naturally have to bear in mind a broader range of factors influencing what would be 
deemed as acceptable/comprehensible/appropriate story-telling in various Arab cultures.

One function of this broader concern is the ways in which Islamic and Arabic mores and social conventions are central to the strategies selected by Arabic translators. Thus we see translations that involve not only translating words, but also considering, for example, Islamic codes and conventions on acceptable dress for characters. We also see translations that consider the ways in which pigs might be perceived by members of a largely Muslim Arab audience. What is often interesting, though, is the contingency of these decisions: thus, in less conservative Egyptian society these conventions will often be less rigorously implemented than elsewhere in the Gulf area. It is also in Egypt that we see a greater sensitivity towards inclusion of characteristics perceived as identifiably Jewish (Uncle Scrooge's top hat) at times of great political sensitivity during moves towards peace between Egypt and Israel.

One function of this is that, as Disney comics are translated from English into Arabic, we not only see the emergence of a range of different ideological, cultural, and social investments in particular elements of the story (top hat, dress, prison numbers, etc.) in the TT, but we also see (partly as a result of this) acts of translation that either noticeably change the story being told or noticeably transform characterisation. This is visible not only in the case of the Beagle Boys, but also in the translation into Arabic of History Re-Petes Itself, in which Mickey ceases to be the bright, well-behaved character we all know and love, and becomes a more menacing character with a greater capacity for cruelty. This transformation of Mickey's character cannot be understood as reflecting the needs and demands of an Arab readership, but it does demonstrate that translation has the capacity to significantly transform comic stories and characters. In illustrating this point, the translation of History Re-Petes Itself also demonstrates the different ways in which readerships in Arab countries and in the West come to "know" Disney. In the West, Mickey reflects all that is fun and harmless about Disney, and is invested with particular significance as a result of his character's positioning vis-à-vis the "American dream." As a result, for the Mickey Mouse storytelling to be convincing in the West, it would have to reflect this. But in Arab countries, Mickey is not invested with the same significance: he may be a largely "good" character, but it is not beyond the scope of possibility to imagine him as a potentially "bad" or cruel character. The re-telling of Mickey Mouse stories in the Arab world reflects this ambivalent positioning and illustrates the ways in which the translation of Disney comics from English into Arabic comes to centre not only around straightforward questions of translation, but also around sedimented social and cultural mores and different story-telling tropes and the ideological investments in these.

My analysis illustrates that the most frequently used strategies of comic translation (reordering, addition, repetition, visual manipulation, omission, deidiomatising and explicitation) are all strategies that have their own politicised dimensions in the re-telling of Disney comic stories in Arabic. This recognition is important, since it demonstrates not only the ways in which translation can impact upon particular storylines or characterisations, but also the ways in which translation recognises and impacts upon the differing ideological investments in these story-telling tools within different political, cultural, religious, and social settings. Such a reading opens the way for further re-politicised readings of Disney comics, not only in their translation into Arabic, but also in the implications of the ST for readers in the Arab world. 


\section{NOTES}

1. I obtained the Arabic Disney stories from Al-Qabas and Disney-Jawa in photocopy format, and in some cases I was unable to locate the source texts in English. Unfortunately, the images could not be reproduced in this article since Disney denied the permission to use the illustrations for which they hold the copyright for research purposes, in spite of my continuous and persistent attempts to this end.

2. Both numerical systems - the Western (1, 2, 3, etc.) and the Arabic (), $r, r$, etc.) - originate from India as early as 200 B.C. and were adopted and developed by Arabs by about A.D. 800. According to Al-Zoman (2001), there were two sets of numbers used by Arabs - Eastern Arabs and Western. Eastern Arabs, specifically in Baghdad, have developed the numerical system that is now used widely by Arabs and Muslims. Western Arabs did some modifications on the numerical system used by Eastern Arabs. Arabs brought this new version to Spain about 900 and then to the rest of Europe about 1100. Europeans modified the numbers to suit their language character set (and they call it Arabic numbers). The European new numbers were taken and used years later by Arabs in the West of the Arab world.

3. It is most plausible to read the inclusion and omission of Uncle Scrooge's top hat in Egypt within a broader political context. During the 1970s the peace process between Egypt and Israel was an extremely sensitive and emotive issue, and one which led eventually to President Sadat's assassination. Earlier comics, in which the top hat is removed, reflect these sensitivities while in later comics it was possible to include Uncle Scrooge's top hat because the peace process had become slightly less contentious over time.

\section{REFERENCES}

\section{Primary Sources}

Battut No. 305, Al-Qabas, 2001.

Battut No. 306, Al-Qabas, 2001.

Ejazah ma'a Mickey Vol. 2, Issue 12, Al-Futtaim Printers and Publishers (no year of publication).

Mickey No. 293, Al-Qabas, 2000.

Mickey No. 304, Al-Qabas, 2001.

Mickey No. 305, Al-Qabas, 2001.

Mickey No. 306, Al-Qabas, 2001.

Mickey Vol. 76 (II), Dar Al-Hilal, 1998.

Mickey Vol. 78 (I), Dar Al-Hilal, 1999.

Mickey Weekly Magazine No. 224, Al-Futtaim Printers and Publishers, 1999.

Mickey Weekly Magazine No. 265, Al-Futtaim Printers and Publishers, 2000.

Super Mickey Vol. 30, Dar Al-Hilal, 1993.

Super Mickey Vol. 32, Dar Al-Hilal, 1994.

Super Mickey Vol. 39, Dar Al-Hilal, 1997.

Super Mickey Vol. 40, Dar Al-Hilal, 1998.

Super Mickey Vol. 41, Dar Al-Hilal, 1998.

Walt Disney's Comics No. 630, Gladstone, 1998.

Walt Disney's Comics No. 633, Gladstone, 1999.

\section{Secondary Sources}

Al-Zoman, A. (2001. 2002): “Arabic Zero," Aug. 12, 2001, Mar. 3, 2002, <http://www.isu.net. sa/archive/ainc-alc/2001-August/000185.html>.

Bellancera, R. (2000): Home Page, Jan. 18, 2001, <http://www.jps.net/xephyr/rich/dzone/ hoozoo/mickey.html>.

Delabastita, D. (1989): "Translation and Mass-Communication: Film and T.V Translation as Evidence of Cultural Dynamics," Babel 35-4, pp. 193-218.

Delabastita, D. (1993): There's a Double Tongue. An Investigation into the Translation of Shakespeare's Wordplay, with Special Reference to 'Hamlet' (Approaches to Translation Studies 11), Amsterdam and Atlanta, Rodopi. 
Douglas, A. and F. Malti-Douglas (1994): Arab Comic Strips: Politics of an Emerging Mass Culture, Bloomington, Indiana University Press.

Finch, C. (1999): The Art of Walt Disney, New York, Harry N. Abrams.

Kainde, K. (1999) "Thump, Whizz, Poom: A Framework for the Study of Comics under Translation," Target 11-2, pp. 263-88. 